\title{
Many steps can be taken to enhance recovery after thoracic surgery
}

\author{
Eliza Sophie Hartmann ${ }^{1}$, Paul Philipp Heinisch ${ }^{2,3,4}$, Markus M. Luedi ${ }^{3}$ and Maks Mihalj ${ }^{2 *}$ (]
}

\begin{abstract}
Our letter to the editor comments on issues raised in the May 14,2020, article by Budacan et al. addressing the development of enhanced recovery after thoracic surgery. In the United Kingdom and Ireland, a nationwide survey identified issues. Here, we expand on the authors'findings.

Keywords: Enhanced recovery after thoracic surgery, ERAS, Cardiothoracic surgery, Operating room management, Optimization, Staffing, Shared decision making, Non-technical skills
\end{abstract}

\section{To the Editor}

We read with great interest the recent article by Budacan et al. describing the variations and difficulties in implementing the current guidelines for enhanced recovery after thoracic surgery (ERAS) in the United Kingdom and Ireland. Through a nationwide survey and using simple descriptive statistics, the authors captured the unfiltered reality of variations in the practice of the ERAS guidelines by a group of medical professionals [1]. The main variations and differences were observed at staffing levels, and included inconsistent teamwork, limited availability of resources over the weekend, and reduced access to established smoking cessation programs, to name a few. While the authors suggested that educating the staff and improving communication and teamwork could improve ERAS in thoracic surgery, we believe that an interdisciplinary approach should also involve operating room (OR) management, human resources, and staffing, as already in practice by some [2].

\footnotetext{
*Correspondence: maks.mihalj@insel.ch

2 Department of Cardiovascular Surgery, Bern University Hospital, University of Bern, Bern, Switzerland

Full list of author information is available at the end of the article Letter to the editor considering the recent publication by Budacan et al., titled "National survey of enhanced recovery after thoracic surgery practice in the United Kingdom and Ireland"
}

Good OR management might also include matched allocation of anesthesiologists, not only to an individual patient but also to a specific surgeon, as this has been shown to improve team performance, and therefore has a positive effect on operating room efficiency through better turnaround times [3]. Further points to consider are the perioperative team setup, patient age, and American Society of Anesthesiology (ASA) risk assessment, as these have been shown to influence OR times [4]. Yang et al. demonstrated that forming dedicated ERAS groups for cardiac surgery increases recovery after cardiac surgery, and should include not only the surgeon, but also the anesthesiologist, the nurses, and the administration [5]. This ultimately helps build team consensus, and supports the consistent use of ERAS by all team members.

Given the comorbidity and risk profiles of cardiothoracic surgery patients, preoperative assessment and detailed planning should include the surgeon as well as the anesthesiologist and other applicable specialists. Preoperative optimization of the patient should be performed whenever possible, including management of medication, coagulation and blood status, anticipated blood management, as well as standardized programs for enhancing the physical and nutritional status [6]. Shared decision-making should involve the surgeon, the anesthesiologist and the patient, and might further improve the implementation of ERAS.

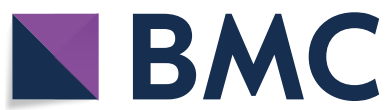

(c) The Author(s) 2021. Open Access This article is licensed under a Creative Commons Attribution 4.0 International License, which permits use, sharing, adaptation, distribution and reproduction in any medium or format, as long as you give appropriate credit to the original author(s) and the source, provide a link to the Creative Commons licence, and indicate if changes were made. The images or other third party material in this article are included in the article's Creative Commons licence, unless indicated otherwise in a credit line to the material. If material is not included in the article's Creative Commons licence and your intended use is not permitted by statutory regulation or exceeds the permitted use, you will need to obtain permission directly from the copyright holder. To view a copy of this licence, visit http://creativecommons.org/licenses/by/4.0/. The Creative Commons Public Domain Dedication waiver (http://creativeco mmons.org/publicdomain/zero/1.0/) applies to the data made available in this article, unless otherwise stated in a credit line to the data. 
Last but not least, Loup et al. demonstrated the importance of non-technical skills (NTS) in the multidisciplinary care of surgical patients. These involve personal and social skills, as well as the cognitive abilities of all team members, including the patient [7]. It is well known that technical skills alone are not sufficient to produce good outcomes in surgical fields, and intraoperative complications or errors may occur not only due to insufficient technical skills, but also due sub-standard commitment and organizational influences, to name only a few [8]. Training programs aimed at increasing the NTS should be offered by all hospital systems. These should address leadership, communication, teamwork and resource management. As these were the main factors identified in the study by Budacan et al., their implementation might further increase the success and consistency of ERAS in (cardio-) thoracic surgery.

\section{Abbreviations}

ASA: American Society of Anesthesiology; ERAS: Enhanced Recovery After Thoracic Surgery; NTS: Non-technical skills; OR: Operating room.

\section{Acknowledgements}

None.

Authors' contributions

All authors wrote, read and approved the final manuscript.

Funding

None.

Availability of data and materials

Not applicable.

\section{Declarations}

Ethics and approval and consent to participate Not applicable.

\section{Consent for publication}

Not applicable.

\section{Competing interests}

None.

\section{Author details}

${ }^{1}$ Department of Anesthesiology, Langenthal Regional Hospital, Bern, Switzerland. ${ }^{2}$ Department of Cardiovascular Surgery, Bern University Hospital, University of Bern, Bern, Switzerland. ${ }^{3}$ Department of Anaesthesiology and Pain Medicine, Bern University Hospital, University of Bern, Bern, Switzerland. ${ }^{4}$ Department of Congenital and Pediatric Heart Surgery, German Heart Center Munich, Technical University Munich, Munich, Germany.

Received: 20 March 2021 Accepted: 19 September 2021

Published online: 28 September 2021

\section{References}

1. Budacan AM, Mehdi R, Kerr AP, Kadiri SB, Batchelor TJP, Naidu B. National survey of enhanced recovery after thoracic surgery practice in the United Kingdom and Ireland. J Cardiothorac Surg. 2020;15(1):95. https://doi.org/ 10.1186/s13019-020-01121-2

2. Wang C, Lai Y, Li P, et al. Influence of enhanced recovery after surgery (ERAS) on patients receiving lung resection: a retrospective study of 1749 cases. BMC Surg. 2021;21:115. https://doi.org/10.1186/ s12893-020-00960-z.

3. Doll D, Kauf P, Wieferich K, Schiffer R, Luedi MM. Implications of perioperative team setups for operating room management decisions. Anesth Analg. 2017;124(1):262-9. https://doi.org/10.1213/ANE.0000000000 001672 (PMID: 27918327).

4. Luedi MM, Kauf P, Mulks L, Wieferich K, Schiffer R, Doll D. Implications of patient age and ASA physical status for operating room management decisions. Anesth Analg. 2016;122(4):1169-77. https://doi.org/10.1213/ ANE.0000000000001187.

5. Yang L, Kaye AD, Venakatesh AG, Green MS, Asgarian CD, Luedi MM, Liu $H$. Enhanced recovery after cardiac surgery: an update on clinical implications. Int Anesthesiol Clin. 2017;55(4):148-62. https://doi.org/10.1097/AlA. 0000000000000168.

6. Mihalj M, Carrel T, Urman RD, Stueber F, Luedi MM. Recommendations for preoperative assessment and shared decision-making in cardiac surgery. Curr Anesthesiol Rep. 2020;10(2):185-95. https://doi.org/10.1007/ s40140-020-00377-7.

7. Loup O, Boggs SD, Luedi MM, Giordano CR. Nontechnical skills in a technical world. Int Anesthesiol Clin. 2019;57(1):81-94. https://doi.org/10. 1097/AIA.0000000000000215.

8. Parissis $\mathrm{H}$, Grath-Soo LM, Al-Alao B, et al. Depicting adverse events in cardiac theatre: the preliminary conception of the RECORD model. J Cardiothorac Surg. 2013;8:51. https://doi.org/10.1186/1749-8090-8-51.

\section{Publisher's Note}

Springer Nature remains neutral with regard to jurisdictional claims in published maps and institutional affiliations.

\footnotetext{
Ready to submit your research? Choose BMC and benefit from:

- fast, convenient online submission

- thorough peer review by experienced researchers in your field

- rapid publication on acceptance

- support for research data, including large and complex data types

- gold Open Access which fosters wider collaboration and increased citations

- maximum visibility for your research: over 100M website views per year
}

At BMC, research is always in progress.

Learn more biomedcentral.com/submissions 